\title{
The Reformation of Business Education: Purposes and Objectives
}

\author{
Robert Shaw \\ The Open Polytechnic of New Zealand
}

\begin{abstract}
Business education is at a critical juncture. How are we to justify the curriculum in undergraduate business awards in Aotearoa New Zealand? This essay suggests a philosophical framework for the analysis the business curriculum in Western countries. This framework helps us to see curriculum in a context of global academic communities and national needs. It situates the business degree in the essential tension which modernity (Western metaphysics) creates and which is expressed in an increasingly globalised economy. The tension is between those who insist that the degree is to serve modernity and those who hope that it may contribute to a new era of justice and harmony with nature. One critical battle ground for the business curriculum is the subject Business Ethics. The business ethics curriculum often indicates the intention of the business ethics degree itself. Kant's distinction between heteronomy (rule following) and autonomy (making your own decisions) provides us with a means to judge the purposes of business ethics courses: there are courses which seek to produce reliable and compliant (heteronomous) employees, and there are those which seek to produce independent creative (autonomous) human beings. The question for this conference is: what do we as business educators see as our task?
\end{abstract}

Keywords: business education aims, business ethics, heteronomy, autonomy 


\section{The Reformation of Business Education: Purposes and objectives}

\section{Introduction}

This essay provides a framework that we can use to assess the purpose, objectives and content of business degrees and diplomas. It contributes to the ongoing debate about how New Zealand institutions should develop their awards. The paper begins with a discussion of context (both local and global), indicates some of the extant drivers of change, and concludes with a typology of concepts that facilitates our purpose. Before we begin, however, let us consider the comments of a successful graduate.

A 31-year-old New Zealand entrepreneur - Luke Howard-Wills - built an eightymillion-dollar online business from scratch. His first website was www.torpedo7.co.nz. What he said about the value of a business degree suggests the role of the degree in the real world of business. As the reporter writes, "He says even with his natural talent at turning a buck, a degree is something you need to do as it teaches you disciplines and research skills" (Horrocks, 2011, p. 24). The word "disciplines" here is delightfully ambiguous, there are disciplines in the sense of structured patterns of through and there are disciplines in the sense of academic disciplines. Both of these possibilities, which are not mutually exclusive, need exploration. The reference to "research skills" holds no ambiguity, and refers to the full range of social science research methodologies which are typically offered in undergraduate degrees.

Apart from his mention of formal study, Howard-Wills describes how he learnt from his father and other people. Essentially, he depicts an informal apprenticeship. "Everything else that I have learnt has come from reading books, and the people that I associate with" (Horrocks, 2011, p. 24). One critical innovation "came to him on a long flight back from Taiwan and the concept scribbled on the back of an Air New Zealand serviette" (Horrocks, 2011, p. 27). This became the website www.1-day.co.nz and subsequently the business model proliferated. The company, which began in Hamilton in 2003 and quickly expanded to Australia, is now a significant employer and contributes to the economic growth of two nations. The reflection on experience which Howard-Wills offers opens for us the vexed question of the purpose of the undergraduate business degree.

Not all business degree students are like Howard-Wills. Many do not embrace their studies. The rising epidemic of dishonest practices in academia is one of the realities educators face. There is some evidence that business degree students, at least in the United States, are those more likely to cheat than students in other disciplines (the research is summarised by Petrick, 2011, p. 363). There is often a "cavalier acceptance of cheating" and those who cheat as undergraduates are more likely to cheat as post-graduates and in professional schools. This probably relates to the "increasingly widespread willingness of 
many job applicants to misrepresent accomplishments" (Petrick, 2011, p. 364). Cheating is facilitated by new technology and distance education institutions are the most vulnerable (Anderman \& Murdock, 2007; Koocher, 1991). Findings about our students such as these lead us to consider with caution both the delivery mode and the purpose of the business degree.

\section{The context of business education}

The vignette indicates the context of business education from a personal point-of-view. Curriculum developers require a wider perspective. They need to see their work within the global human context which transcends national, social and economic conditions. The first task in writing a prescription is to determine its purpose and objectives: developers will only achieve a firm foundation for their curriculum if they appreciate the global historical context in which the course will be delivered.

There are two levels of description to consider. The first is to establish business education in that context which indicates its global significance in terms of the evolution of humankind and the grounding which determines our pattern of existence. At this level of description people say we are within modernity. They refer only to Western nations and traditions. Modernity is that ethos or spirit of the age which embraces us all and sets up for us the parameters of our thinking. Most characteristic of our time is what we refer to as technology and modern science. The age in which we live began with Galileo and Newton primarily it was the insight that the physical universe is mechanical and that human beings are able to discern the laws of nature. These laws are at their best when they are mathematical. The belief that we can understand mature and use this understanding to advance humankind now pervades Western nations. Attracted by the material success that this attitude has produced (a few years ago Western nations were exclusively the high GDP nations), many non-Western nations seek to emulate the West. China is an example: they missed the industrial revolution and now seek to catch up. Likewise, India and many of the Islamic nations are modernising. One part of this process is the expansion of education, particularly in science, technology and business.

The second level of context that is relevant as we seek to sketch the context of the business degree relates to the economic theory that pervades Western nations. This theory itself - neo-liberalism - is an expression of modernism. Its leading tenants are a belief in competition and private enterprise as expressed through the operation of honest markets (de Alba, González-Gaudiano, Lankshear, \& Peters, 2000). Neoclassical economic theory, along with the theory that we associate with John Maynard Keynes, dominates mainstream economic thinking. Competition, supply and demand, customers, consumer choice, the importance of profits, honesty, and the rights of individuals are all notions which derive from the economic context of neo-liberalism. Hidden within this is the belief that reasoning or rationality is important. It is not just the controversial notion that markets or market players are rational, but the wider application of rationality as a means to solve problems and a way to decide how to comport yourself in the business world. The belief in rationality in business 
is the same belief that Galileo achieved in the discovery of the mechanical universe. It is apparent in our interest in evidence and measurement. Discover the facts and be precise, they say. These are the hallmarks of modern science - and of modern business. They are also prominent in education theory and work on New Public Management within New Zealand (Devine, 2003, 2004, 2005; Lodge \& Gill, 2011).

Business as an enterprise is an inextricable expression of neo-liberalism and modernity. If the business degree is the handmaiden to business it also must have these characteristics. It should not be thought that this is necessary undesirable or inappropriate. The task here is to merely describe the context of business education, and not to enter moral or political judgements. Several authors explore both normative and descriptive renditions of these ideas (M. A. Peters, 2001, 2002). Although, one fact dominates this whole discussion: for reasons that need not be rehearsed here nations with limited resources aspire to educate more people than ever before and to a higher level. Education has become a numbers game and what dominates institutions is not educational goals but budget figures, the popularity of courses, sales and course completions. The governmental educational response to the plethora of courses, the diversity of students and the variability of institutions, is the auditing of everything. As we might expect, the procedures of auditing exemplify the hallmarks of modernity. There are precise criteria, procedures, and much ticking and crossing. There is little engagement with the philosophy of education. Management theorists notice in government audit procedures the old adage "if you cannot measure it you cannot manage it" which became popular in association with recent initiatives such as the "Balanced Scorecard" model for business reporting. Drucker became popular with some because of his attempt to modify this positivist imposition.

Neo-liberalism and modernity can dominate business education. This is apparent in recent tendencies within some schools of business. Within just the last two decades we have seen the hegemony of positivism in business research and business teaching, and the transmutation of pedagogy into instruction. At the extreme, in some institutions teaching has become "course delivery" whilst curriculum development has become fragmented into tasks such as marketing research, instructional design, course writing and platform building. All this obviates the need for insightful and skilled teachers. It also ossifies the curriculum - no longer is it necessary for teachers to be at the forefront of their discipline. What is taught is of less importance than the numbers of students who complete courses and awards. Educational institutions become credentialing factories when driven by the neo-liberal demands of government.

This pervasive reality contrasts with the work of outstanding academics and some institutions (or more commonly, departments within institutions). Judgements about who these people are can only be made by each of us on the basis of our direct experience with their work. Most university business schools claim to have "world-class experts in their field" and refer to rankings from various ratings organisations. It is noticeable that in several Asian institutions there is an acute interest in work which seeks to overcome the limitations of modernity - which apparently conflicts with the objective of economic prosperity. The 
National Sun Yat-Sen University's project on the phenomenology of entrepreneurship is an example (Shaw, Dun-Hou Tsai, \& Amjadi, 2011). However, this interest has a suggested rationale. As Asian nations seek to modernise they adopt the practices of the West though meteoric and expeditious development programmes. It is important to avoid a misunderstanding about this, though. Their interest in material achievement is driven by fundamental human need (living conditions, calorific intake and the ability to contribute to society) and not by a desire for cultural or spiritual change. It is apparent that Asian business schools emulate America schools in a limited number of ways. They are like Māori in Aotearoa New Zealand who say they want their children to be competent in both the Pākehā (European) world and in Te Ao Māori (the Māori world) but encounter conflicts (Shaw, 2011). In the discussion which follows examples of worthwhile curriculum innovations and initiatives in pedagogy appear.

Neo-liberalism is apparent in the commercial ventures of business schools. When commercial purposes dominate the provision of the business degree there are repercussions for curriculum. This is apparent when universities seek to expand their business into new countries. It might be thought that the psychologists' assertion that teaching must be appropriate for the student taught would be important in new countries. Thus, if you move to China you address the pedagogic needs of your Chinese students and build a new curriculum accordingly. Many universities adopt a strategy of internationalisation in an effort to expand their influence and generate funds. Business schools particularly take up the challenge of dispersed campuses and culturally diverse students, and New Zealand schools have expressed aspirations. In Singapore, for example, there are a plethora of international universities courting students from countries like China, Vietnam, Cambodia, and Thailand - indeed even from Europe. Some Australian universities, such as James Cook University (based at Townsville) and The University of Newcastle (New South Wales), offer Australian accredited degrees with the same curriculum that they offer in Australia. Their courses teem with fee-paying students who are anxious for Australian accreditation. Providers from other countries also offer their home curricula in Singapore, for example, the esteemed American institution The University of Chicago Booth School of Business. The renowned Institut des Sciences Economiques et Commerciales (Institute of Economic and Commercial Sciences), ESSEC, with its distinctive focus on ethics and humanism in business, has campuses in France and Singapore. It is an Institute which emphasises the integration of the students' academic work with the experience of companies. With the support of the Singapore Government such schools can achieve rapid expansion. There are also examples of transplants which have not gone well and often these do not have the direct involvement of the Government in the target country.

The critical educational matter to consider in such multi-campus ventures is whether the curriculum offered in an Asian nation ought to be that offered in Australia or France, the United State of America or New Zealand. The confrontation is distinctly between the institutions of Western nations and aspirations of individuals outside of that successful club. It is very apparent that large numbers of Asian students seek the hosts "home country" 
credential in Singapore, and it will be provided, but is it educationally sound? The immediate answer to this question draws upon the earlier discussion about the hegemony of Western institutions and their complicity in the expansion of Western modernity. It is not argued here that this of itself is a bad thing. On the contrary, there are plenty of examples which display commendable initiatives. For example, at the Technical University of Lodz (Poland) the management curriculum is being used as a vehicle to advance sustainability and ecoengineering not just within courses but also in outreach programmes (Doniec, 2006). The issues about the quality of curriculum and pedagogy that these examples raise are of concern

\section{The core of a business degree}

It should not surprise those that have read this far that there are two distinctive accounts of the purpose of a business degree. The first is the view which accepts the strictures of modern metaphysics - here described as modernity primarily expressed though neo-liberal economics. Businesses show their success through their viability in a capitalist environment and the purpose of the business degree is to facilitate such success. This view has for at least twenty years dominated business education. Accordingly, it may be dubbed the received view.

The second account of the purpose of a business degree answers the call of many political and business leaders for insightful, inspirational, community government and business leadership. They say leadership should be transformational and businesses schools must lead in global and personal transformations. Accordingly, we need business people able to see beyond the constraints of our immediate situation and contribute to our advancement into a qualitatively different environment. Those purposes and objectives for business degrees which address this need are alternatives to the received view.

\section{The received view}

If we accept that a business degree is an expression of Western metaphysics, and seek to support that enterprise, how might we conceive of the degree? The components must provide a foundation for both employment and further education which is also directed at employability.

Business processes themselves, as extant today, dictate much of the content of business degrees. The best example of this is accounting. There are few people in business who do have a need for accounting skills and an understanding of standard accounting principles. The foundation of accounting is a different matter. Practical accounting is primarily about categories, decision-making in situations of incommensurable choice, and planning/budgeting. The foundational, intellectual disciplines that give us insight into these things are branches of philosophy. We see the transition from practice to premise in an enquiry into the relationship between corporate social responsibility and management accounting. Its authors relate the current state of society to the role of accounting within society. In practice the course the develop in response to their concerns is conventional, it draws upon invited speakers and topics such as research methods, sustainable business, 
corporate governance, and whistle blowing (Kelly \& Bather, 2009, p. 23). What is remarkable is the extent to which their students engage with the Organisations \& Society course. This, its lecturers claim, is the result of a changed business environment: "As recently as 10 years ago students at our university were being taught in many classes that the only purpose of business in society is to maximise the wealth of shareholders. Today most of our colleagues have ceased to promote such a message" (Kelly \& Bather, 2009, p. 26). Alternations in the beliefs of teachers and students alike can influence course development, and in this management accounting example there appears to have been in the 1980s a move towards an alternative to the received view.

\section{Alternatives to the received view}

If we do not accept that the business degree ought to be an expression of Western metaphysics we must ask what the degree is to express. The question posed ceases to be about business education and becomes about the purposes of education itself.

Alternatives to the received view have traditions of their own dating from at least 1881 and 1925 in the United States of America. Joseph Wharton founded the Wharton School at the University of Pennsylvania in Philadelphia in 1881. He asserts that the guiding principle - the broad purpose and mission - of the School is "to serve the community skilfully as well as faithfully in offices of trust" (Khurana \& Gintis, 2008, p. 55). The Wharton School of Finance and Economy, as it was first called, only accepted students who had completed two years of either a classical or scientific college education (James, 1891, p. 20). In 1925 the dean of the Harvard Business School spoke at Stanford University's School of Business. Dean Bonham assailed his audience, American business schools had become schools for "brokers, bankers, consultants, and entrepreneurs" he said. Bonham argues that business education must return to its foundational conception in America. The essential discipline within the business degree is management and that discipline seeks to produce graduates who are on a "higher ethical plane", "socially motivated", and dedicated to handle "business problems in socially constructive ways" (Khurana \& Gintis, 2008, p. 55).

One prominent expression of interest in alternatives to the received view in the United Kingdom is the renascence that the philosophy of management currently enjoys. When the journal Philosophy in Action changed its name to The Philosophy of Management there was an immediate upsurge in interests.

Substantial alternatives to the received view are found in the work of specific theorists. For example, the Finnish scholar Esa Saarinen develops a philosophy of management on the basis of his extensive experience with businesses (Saarinen, 2008, p. 3). The benefits for managers of the curriculum he develops relates to self-leadership, the understanding of wholes, and insights into activity in complex environments (Saarinen, 2008, p. 3). The discipline of philosophy, he says, incorporates the right and even the duty to study the bigger picture (in this he draws upon Whitehead) and this includes "the bigger picture of a small picture, a locality, that of an individual human being in the mist of her immediate context" (Saarinen, 2008, p. 4). He also addresses the managers' search for a style and 
philosophy for managers as a philosophy of life. On this latter topic, he makes it plain that he is not advocating that philosophy for managers becomes a delivery channel for particular themes, rather: "Philosophy that is charged for dialogue and for significance to managers' lives seeks resonation and vibrations with energising, life-enhancing productivity" (Saarinen, 2008, p. 12). This is a comment which suggests philosophy may also support the received view.

\section{Business ethics}

The tussle over the purposes of business ethics courses, and indeed even their presence in the business degree, exemplifies the tension between the received view of the business degree and the alternatives to the received view. Business ethics courses are increasingly supported in major universities and "stand alone" courses are compulsory for business students in 60 percent of the "top business schools" in America (2008 data in Litzky \& MacLean, 2011). Without further information about course purposes this statistics does not tell us a great deal.

We can distinguish between course objectives if we make use of (1) the already explained distinction between the received view and other views, (2) Kant's distinction between heteronomy and autonomy (Kant, 1997). For our purposes it is sufficient to say that heteronomous persons follow (external, given) rules, and autonomous persons deliberate on moral decisions and seek to implement their own decisions (R. S. Peters, 1959, 1970). The psychologists Piaget and Kohlberg show how the ability to produce heteronomous judgements develops before the ability to be autonomous (Piaget, 1948). Work on judgement and rule following should not be allowed to disguise the complexity of morality itself (Shaw, 1976).

\section{The goals of business ethics courses:}

1. The received view
a. Heteronomy
b. Autonomy

2. Alternatives to the received view
a. Heteronomy
b. Autonomy

Of course such a typology is in practice compromised in all manner of configurations. The purpose here is, however, to enable us to discuss business ethics course objectives in a systematic and productive way. The reader will forgive the caricature that follows.

It is not difficult to identify authors who support the received view: they usually begin their papers with references to dishonesty in business practice and few can resist the temptation to mention Enron. They respond to the calls of politicians for greater integrity in 
business dealings and support the imposition of rules, such as those many countries have now introduced in a bid to regulate banks and critical markets such as the housing market. Some authors express concern about how well curriculum coordinators respond to these pressures and some argue that there is only a "perceived deficiency in the degree of integration of ethics and social responsibility into various specific disciplines" (Nicholson \& DeMoss, 2009). Whatever the extent of integration and course provision, the purpose of business ethics, and indeed the business degree itself, is that of handmaiden to business. The role of the business school is to produce honest business managers. Often those involved deem honest managers to be those who follow the law, a professional code of conduct, or some other code of conduct such as the Christian Decalogue or the Code of the U.S. Fighting Force which begins "I am an American, fighting in the forces which guard my country and our way of life" (Army Public Affairs, 1988, p. 3).

The autonomous ethical decision-maker who supports the received view is the theorist of society who seeks to advance the Western way of life. The emphasis is often on the compromises which we must make to secure our future, and the concept of 'sustainability' is frequently prominent. The "corporate social responsibility" and "triple-bottom-line reporting" crusades are largely expressions of autonomous moral decision-making in the interests of society. In terms of Kohlberg's stage theory of moral development, these people are level 5. They are moral decision-makers who appeal to universal ethical principles and abstract reasoning. At stage 5, people deliberate on principles of justice, particularly when they conflict with laws and rules. Such people place high value on the interests of society, they often support utilitarianism, and in the context of business decision-making the concept of 'stakeholders' is prominent. Thus, we have the ethics of the civil servant and the politician in democratic countries. The instinct to compromise that typifies those who support the received view extends across "social, economic, and moral concerns" and leads Hoffman to call for a "meaningful reciprocity" between these and "practical concerns" (Hoffman, 1984).

A noteworthy set of principles which exemplify autonomous decision-making in accordance with the received view was launched at the United Nations Global Compact Leaders Summit at Geneva in 2007. The Principles for Responsible Management Education (PRME) is the foundational code of this organisation which seeks to "inspire and champion responsible management education, research and thought leadership globally" (PRME, 2011).The principles are:

1. Purpose: We will develop the capabilities of students to be future generators of sustainable value for business and society at large and to work for an inclusive and sustainable global economy.

2. Method: We will create educational frameworks, materials, processes and environments that enable effective learning experiences for responsible leadership.

3. Research: We will engage in conceptual and empirical research that advances our understanding about the role, dynamics, and impact of corporations in the creation of sustainable social, environmental and economic value. 
4. Partnership: We will interact with managers of business corporations to extend our knowledge of their challenges in meeting social and environmental responsibilities and to explore jointly effective approaches to meeting these challenges.

5. Dialogue: We will facilitate and support dialog and debate among educators, students, business, government, consumers, media, civil society organizations and other interested groups and stakeholders on critical issues related to global social responsibility and sustainability. We understand that our own organizational practices should serve as example of the values and attitudes we convey to our students.

Over 370 corporations in 60 countries now subscribe to the organisation that seeks to influence governments, regional organisations, trade unions, NGOs and media organisations (Kell \& Haertle, 2011, p. 16). "Sustainable value" and "an inclusive and sustainable global economy" - these are the concepts of those who seek to direct business ethics at the improvement of existing structures. Some commentators question the purpose of PRME. They note, for example, that the "principles are deliberately designed in a rather broad way sot that adopting institutions have the necessary free space to come up with contextualized solutions that fit their respective context" (Waddock, Rasche, Werhane, \& Unruh, 2011, p. 19). The same authors question the relationship between PRME and academic freedom (ibid, p.19). It seems desirable (to the present author at least) that those involved in the practice of management and foundational courses in management education be given a pathway to more profound reflections about management. PRME provides valuable institutional support at the interface of practice and education within the strictures of modernity.

Those who are heteronomous and support alternatives to the received view (remembering that the received view is Western metaphysics, modernity) include the "mindless" rule followers who seek to oppose Western nations through covert or violent means. The passive followers of cult leaders and ideological mantra - religious or green - are also heteronomous decision-makers. It should not be thought that heteronomy is undesirable for it is a prevalent approach to moral decision making in Western communities and perhaps it have a more extensive role in relation to autonomy than we might suspect (Day, 2009, appraochs this topic in relation to aesthetic and moral judgement).

The autonomous person who does not accept the strictures of the received view is exemplified by those who seek to take Western countries beyond capitalism (Baofu, 2005; Barkan, 1994; Brick, 2006; Bruyn, 2005; Danielsson, 1978; Handy, 1998; Kostopoulos, 1986; Lanz, 2008). The discussion of these works might occur in courses that have the title "Business \& Society". If we were to strengthen the sociological justification of the business degree in the official syllabus, the business ethics curriculum might well address the nature of society. The ability of official documentation to influence curriculum in this ways is a given (O'Neill \& O'Neill, 2008). One common theme is that "steady-state capitalism" is not attainable and that each of us in business must work towards a more new paradigm of society 
and business, one which involves a new organising principle (compare this with 'profit', say) and indeed a new concept of "democracy" (Smith, 2010, p. 42).

In the realm of courses on business ethics and social responsibility there are many authors who seek to challenge the received view. For example, "the worldview underpinning all management education" is a topic in need of attention according to two authors (Giacalone \& Thompson, 2006, p. 266; , mention should also be made of Haase, 2008). In New Zealand the challenge to the received view comes from Māori who now address the limits of democracy in their work on the New Zealand constitution and in political processes (Shaw, 2007, 2011).

\section{Conclusion}

Business education is Aotearoa New Zealand is by-in-large an expression of modernity and it displays a strong adherence to one economic theory, namely that of neo-liberalism. New Zealand, however, has a choice: it can seek to continue on the current pathway or it can seek to develop a unique New Zealand business culture and ethos. Curriculum developers must confront this situation when they set out the purposes and objectives for awards and courses. There is scope to increase the engagement by business school members with their colleagues who write about education theory. There are welcome signs of a growing interest in societies which facilitate research into business education (one might cite the Distance Education Association of New Zealand, http://www.deanz.org.nz, which shows a significant interest in business education).

The present paper sets out as framework (a model) to facilitate discussion about the purposes of an undergraduate business degree. That framework uses Kant's concepts of heteronomy and autonomy to examine the purposes of business degrees. The academic literature suggests that globally those who deliver such degrees have begun to question their fundamental rationale. The notion that the business curriculum can be set by an institution in accordance with some mission of the institution, or (as was common in New Zealand) the desire to appeal to a target market, is naive. There are important lessons for those who would mould the business curriculum for their own ends. It remains a truism that the most powerful influence on curriculum is teachers. Recent work on the teachers' community of practice demonstrates the importance of teachers in the implementation of new curricula (see the papers at http://communitiesofinquiry.com/papers_coi). As another example of the importance of teachers in curriculum development, there is a socio-cultural analysis of the implementation of an innovative New Zealand physics curriculum which was "compromised by the lack of any intersubjective linkage between teachers and curriculum designers (Fernandez, Ritchie, \& Barker, 2008, p. 187). That is a polite way of saying the teachers ignored the new curriculum. This is a secondary school example, and we might expect the autonomy and intransigence of teachers to be even greater in tertiary education where there is a tradition of academic freedom and autonomy. Marginalised curriculum planners waste public resources. If those who plan and write curriculum documents for business degrees do not adequately engage with teachers they will find that the "cultural objects they have 
developed will be adopted in unanticipated ways" (To use a borrowed expression, Fernandez, et al., 2008, p. 187).

Finally, as alternatives to the received view become more prominent we can expect to see greater demand for a diversity of courses in business degrees. Not only are business ethics courses becoming more ambitious, but there is also a demand that they be complemented by business and society courses. Recent research - such as that of John Searle on the nature of institutions and organisations (Searle, 2010) - could be prominent in such courses, and we may predict that they will find great credibility with students such as the young entrepreneur Howard-Wills.

\section{References}

Anderman, Eric M., \& Murdock, Tamera Burton. (2007). Psychology of academic cheating. Amsterdam ; Boston: Elsevier Academic Press.

Army Public Affairs. (1988). Code of the U.S. fighting force. Washington, D.C.: Department of Defence.

Baofu, Peter. (2005). Beyond capitalism to post-capitalism : conceiving a better model of wealth acquisition to supersede capitalism. Lewiston: E. Mellen Press.

Barkan, Joel D. (1994). Beyond capitalism vs. socialism in Kenya and Tanzania. Boulder: L. Rienner.

Brick, Howard. (2006). Transcending capitalism: visions of a new society in modern American thought. Ithaca: Cornell University Press.

Bruyn, Severyn Ten Haut. (2005). A civil republic: beyond capitalism and nationalism. Bloomfield, CT: Kumarian Press.

Danielsson, Christer. (1978). Business and politics, towards a theory beyond capitalism, Plato and Marx. Helsingfors: Swedish School of Economics and Business Administration.

Day, Gail. (2009). The Fear of Heteronomy. Third Text, 23(4), 393-406. doi: 10.1080/09528820903007677

de Alba, Alicia, González-Gaudiano, Edgar, Lankshear, Colin, \& Peters, Michael A. (Eds.). (2000). Curriculum in the Postmodern Condition. New York: Peter Lang.

Devine, Nesta. (2003). Politicising technology and technologising politics. Access : Critical Perspectives on Communication, Cultural and Policy Studies, 22(1/2), 67-72.

Devine, Nesta. (2004, 26-27 November, 2004). Democracy, education and the subject. Paper presented at the 33rd Annual Philosophy of Education Society of Australasia Conference: Education and values, Melbourne.

Devine, Nesta. (2005). Derrida, democracy and public choice theory. Access: Critical Perspectives on Communication, Cultural \& Policy Studies, 24(1\&2), 67-74.

Doniec, Andrzej. (2006). Sustainability questions in the curriculum of Faculty of Organization and Management at the Technical University of Lodz. Clean Technologies and Environmental Policy, 8(1), 20-23.

Fernandez, Teresa, Ritchie, Garth, \& Barker, Miles. (2008). A sociocultural analysis of mandated curriculum change: the implementation of a new senior physics curriculum in New Zealand schools. Journal of Curriculum Studies, 40(2), 187-213.

Giacalone, Robert A., \& Thompson, Kenneth R. (2006). Business Ethics and Social Responsibility Education: Shifting the Worldview. [Article]. Academy of 
Management Learning \& Education, 5(3), 266-277. doi:

10.5465/amle.2006.22697016

Haase, Michaela. (2008). Theory, Practice, and Education: On the Role of Business Ethics for Management Education at Business Schools or Universities. In Christopher Cowton \& Michaela Haase (Eds.), Trends in Business and Economic Ethics (pp. 229-261): Studies in Economic Ethics and Philosophy. Berlin and Heidelberg: Springer.

Handy, Charles B. (1998). The hungry spirit: beyond capitalism : a quest for purpose in the modern world (1st ed.). New York: Broaday Books.

Hoffman, W. Michael. (1984). Ethics in Business Education: Working Toward a Meaningful Reciprocity. [Article]. Journal of Business Ethics, 3(4), 259-268.

Horrocks, Nigel. (2011). Switched on CEO: Ten tips for winning online: Luke HowardWillis, Torpedo7, iStart: Technology in Business, pp. 22-27.

James, Edmund J. (1891). Education of business men. An address before the convention of the American bankers' association at Saratoga, September 3, 1890. New York: W. B. Greene.

Kant, Immanuel. (1997). Foundations of the metaphysics of morals, and, What is enlightenment? (Lewis White Beck, Trans.). Upper Saddle River, New Jersey: Prentice-Hall.

Kell, Georg, \& Haertle, Jonas. (2011). UN Global Compact and Principlies for Responsible Management Education: the next decades. EFMD Global Focus, 05(02), 14-16.

Kelly, Martin, \& Bather, Andrea. (2009). Corporate social responsibility and the teaching of managment accounting. Philosophy of Management, 8(1), 15-26.

Khurana, Rakesh, \& Gintis, Herbert. (2008). What is the purpose of business? BizEd, 2008 54-55.

Koocher, Gerald P. (Ed.). (1991). Ethics \& behavior: Special issue: Academic dishonesty. Hillsdale, N.J.: Lawrence Erlbaum Associates.

Kostopoulos, Tryphon. (1986). Beyond capitalism: toward nomocracy. New York: Praeger.

Lanz, Tobias J. (2008). Beyond capitalism \& socialism : a new statement of an old ideal : a twenty-first century apologia for social and economic sanity. Norfolk, Va.: Light in the Darkness Publications.

Litzky, Barrie E., \& MacLean, Tammy L. (2011). Assessing business ethics coverage at top U.S. business schools. In Diane L. Swanson \& Dann G. Fisher (Eds.), Toward assessing business ethics education (pp. 133-142). Charlotte, N.C.: Information Age.

Lodge, Martin, \& Gill, Derek. (2011). Toward a New Era of Administrative Reform? The Myth of Post-NPM in New Zealand. Governance, 24(1), 141-166. doi: 10.1111/j.1468-0491.2010.01508.x

Nicholson, Carolyn Y., \& DeMoss, Michelle. (2009). Teaching Ethics and Social Responsibility: An Evaluation of Undergraduate Business Education at the Discipline Level. Journal of Education for Business, 84(4), 213.

O'Neill, Anne-Marie, \& O'Neill, John. (2008). How the official curriculum shapes teaching and learning. In Alison St George, Seth Brown \& John O'Neill (Eds.), Facing the Big Questions in Education: Purpose, Power and Learning (pp. 3-13). Melbourne: Cengage Learning Australia.

Peters, Michael A. (2001). Education and culture in postmodernity the challenges for Aotearoa/New Zealand. Auckland: University of Auckland.

Peters, Michael A. (Ed.). (2002). Heidegger, education, and modernity. Lanham, Md.: Rowman \& Littlefield.

Peters, Richard Stanley. (1959). Authority, responsibility, and education. London: Allen \& Unwin. 
Peters, Richard Stanley. (1970). Ethics and education. London: Allen and Unwin.

Petrick, Joseph A. (2011). Character assessment in business ethics education. In Diane L. Swanson \& Dann G. Fisher (Eds.), Toward assessing business ethics education (pp. 361-380). Charlotte, N.C.: Information Age.

Piaget, Jean. (1948). The moral judgement of the child (Marjorie Gabain, Trans. 1st American ed.). Glencoe, Ill.: Free Press.

PRME. (2011). Principles for Responsible Managment, from www.unprme.org/

Saarinen, Esa. (2008). Philosophy for managers: Reflections of a practioner. Philosophy of Management, 7(Supplement), 1-24.

Searle, John R. (2010). Making the social world: the structure of human civilization. Oxford: Oxford University Press.

Shaw, Robert Keith. (1976). Assessing components of morality : the development of tests for two of John Wilson's moral components Retrieved from http://hdl.handle.net/2292/2466

Shaw, Robert Keith. (2007). The peculiar place of Enlightenment ideals in the governance concept of citizenship and democracy. In Michael A Peters, Harry Blee, Penny Enslin \& Alan Britton (Eds.), Handbook of global citizenship education (pp. 153-168). Rotterdam, The Netherlands: Sense Publishers.

Shaw, Robert Keith. (2011). The Nature of Democratic Decision-making and the Democratic Panacea. Policy Futures in Education, 9(1), 145-151.

Shaw, Robert Keith, Dun-Hou Tsai, Stephen, \& Amjadi, Mansour. (2011). The Ontology of Entrepreneurship: A Heideggerian perspective. Paper presented at the Conference of the Australian and New Zealand Academy of Management, Wellington.

Smith, Richard. (2010). Beyond growth or beyond capitalism? real-world economics review(53), 28-42.

Waddock, Sandra, Rasche, Andreas, Werhane, Patricia H., \& Unruh, Gregory. (2011). The principles for responsible management education: implications for implementation and assessment. In Diane L. Swanson \& Dann G. Fisher (Eds.), Toward assessing business ethics education (pp. 13-28). Charlotte, N.C.: Information Age. 